\title{
Height-diameter allometric equations of an emergent tree species from the Congo Basin
}

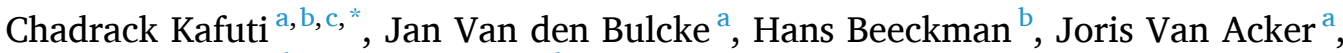 \\ Wannes Hubau $^{\mathrm{a}, \mathrm{b}}$, Tom De Mil ${ }^{\mathrm{a}, \mathrm{d}}$, Hulda Hatakiwe ${ }^{\mathrm{e}}$, Brice Djiofack ${ }^{\mathrm{e}}$, Adeline Fayolle ${ }^{\mathrm{d}}$, \\ Grace Jopaul Loubota Panzou ${ }^{\text {f }}$, Nils Bourland ${ }^{\text {b,e,g }}$ \\ ${ }^{a}$ UGent-Woodlab, Laboratory of Wood Technology, Ghent University, Coupure Links 653, 9000 Gent, Belgium \\ ${ }^{\mathrm{b}}$ Service of Wood Biology, Royal Museum for Central Africa, Leuvensesteenweg 13, 3080 Tervuren, Belgium \\ ${ }^{\mathrm{c}}$ Faculty of Agricultural Sciences, Department of Natural Resources Management, University of Kinshasa, PB. 117 Kinshasa XI, DRC \\ ${ }^{\mathrm{d}}$ TERRA teaching and research center, Gembloux Agro-Bio Tech (Université de Liège), Passage des Déportés 2, 5030 Gembloux, Belgium \\ ${ }^{\text {e }}$ Center for International Forestry Research, Situ Gede, Sindang Barang, Bogor (Barat) 16115, Indonesia \\ ${ }_{\mathrm{f}}^{\mathrm{f}}$ Laboratoire de Biodiversité, de Gestion des Ecosystèmes et de l'Environnement (LBGE), Faculté des Sciences et techniques, Université de Marien Ngouabi, BP. 69 \\ Brazzaville, Republic of Congo \\ ${ }^{g}$ Resources \& Synergies Development Pte Ltd., Raffles Quay 16, \#33-03 Hong Leong Building, Singapore
}

\section{A R T I C L E I N F O}

\section{Keywords:}

Pericopsis elata

Congo Basin

Tropical forest

Allometry

Modelling tree height

Biomass estimation

\begin{abstract}
A B S T R A C T
Reliable tree height-diameter (H-D) allometric equations are a key tool for the estimation of forest productivity and Above Ground Biomass (AGB). Most existing H-D allometric equations developed for the tropical region are based on large-scale multi-species datasets, and their use to derive information on productivity and AGB at the species level is prone to uncertainties. The single-species H-D allometric equations available are mainly focused on monocultures or stands with simple tree species mixtures and did not account for the site effects. Here we measured the height and diameter of 2,288 trees of the emergent tree species Pericopsis elata (Harms) Meeuwen in the Democratic Republic of the Congo (DRC) and in Cameroon. We first examined how accurate multispecies H-D allometric equations are in predicting the total height of $P$. elata. We then tested whether single-species H-D allometric equations vary between sites. We developed the first $\mathrm{H}-\mathrm{D}$ allometric equation of $P$. elata and tested whether and how stand-level and environmental variables induce changes in H-D allometric relationship of $P$. elata at the regional level. We additionally evaluated whether tree-level variables are important at the local level where climate and stand development stage are expected to be less variable. We found that pantropical, regional and local H-D allometric equations significantly underestimate the total height of $P$. elata. The local multi-species H-D allometric equation developed for Yangambi showed the highest underestimation in all the studied sites. This result supports the need for an H-D allometric equation specific for $P$. elata. The species-level H-D allometric equation developed showed significant underestimations for trees from the disturbed and undisturbed forests in DRC, while overestimations were observed for similar sites in Cameroon. Using a mixedeffect H-D allometric equation, we showed that even within a single species, a substantial variation exists between sites. This variation showed to be driven by the differences in the maximum asymptotic height $\left(H_{\max }\right)$ between sites. We found that $P$. elata trees are taller and attain higher $H_{\max }$ in DRC than in Cameroon. The basal area showed to be a significant covariate accounting for the site effects at the regional-scale where climate variables showed minor effects. However, at the local-scale, none of climate or stand variables showed to be significant. Local-scale variation showed to be associated with differences in light availability, highlighting the potential of management options that shape the local environment in driving species productivity.
\end{abstract}

\footnotetext{
* Corresponding author at: UGent-Woodlab, Laboratory of Wood Technology, Ghent University, Coupure Links 653, 9000 Gent, Belgium.

E-mail address: chadrack.kafuti@ugent.be (C. Kafuti).
} 


\section{Introduction}

Tree height is a key variable in the assessment of forest productivity and the calculation of Above Ground Biomass (AGB). Site quality, which is often used as a proxy for site productivity, is constructed based on tree height. Site quality corresponds to the height of dominant trees at a base age (site index) for even-aged forests and to the height at a given diameter (site form) for uneven-aged mixed forests (Moreno-Fernández et al., 2018). The taller a tree is at a given age or diameter on a site, the better the site is (Vanclay, 1994). Considering the positive relationship between tree height and AGB, a better site therefore corresponds to a site with relatively higher AGB production. Tree height and AGB are functionally related. Uncertainty in the estimation of AGB is significantly reduced when tree height is included as a predictor together with tree diameter or wood density. Yet despite their importance, tree height measurements are not always available nor feasible, especially in tropical forests. Accurate allometric equations are therefore required to infer height from easily measurable variables such as trunk diameter at breast height. The increasing number of H-D allometric equations available, shows significant variations between forest types and regions. Understanding the drivers of these variations provides insight into the factors affecting forest productivity and allow predicting its future performance. Unfortunately, conflicting results are currently reported in the literature.

A study at the pantropical level by Banin et al., (2012) showed that precipitation seasonality, basal area, stem density, solar radiation and wood density explained some variations in H-D allometric relationship and maximum height between tropical regions. Yet, even after accounting for these variables, they found that continental differences persisted. Similarly, Feldpausch et al., (2011) found that annual precipitation coefficient of variation, dry season length, mean annual air temperature and vegetation structure captured some variations in H-D allometric relationship between tropical regions. Again, they found that these variables failed to capture the entire region-specific variation in $\mathrm{H}$ $\mathrm{D}$ allometric relationship of tropical trees. These results suggest that forest structure and climate are not sufficient to explain variations in $\mathrm{H}$ D allometric relationship at the pantropical level. Therefore, a single model is not enough to predict tree height all over the tropical forest. However, the inclusion of the stress variable $E$, an index combining temperature variability, precipitation variability and drought intensity, was sufficient to account for the site effect (Chave et al., 2014). This result suggests that climate is an important driver regionally and thus a unique $\mathrm{H}$-D allometric equation including the stress variable $E$ could be used to predict tree height across the tropics. This stress variable $E$ is a compound index combining temperature seasonality, precipitation seasonality and drought intensity. It corresponds to the amount of time a plant is exposed to stressful temperature. A pantropical H-D model including the $E$ variable as predictor was therefore fitted. This pantropical H-D allometric equation was tested by Kearsley et al., (2017) and Fayolle et al., (2016) on data from the DRC and Cameroon respectively and overestimations were reported. Similarly, regional H-D allometric equations (Banin et al., 2012; Feldpausch et al., 2012, 2011; Lewis et al., 2009) failed to better predict tree height. These results suggest that large-scale H-D allometric equations are subjected to significant uncertainties and errors that may dramatically affect broadscale assessment of forest productivity and carbon stock (Feldpausch et al., 2012, 2011). Local or site-specific allometric equations, therefore, are needed. A study by Molto et al., (2014) showed that AGB estimates are more accurate using tree height predicted by site-specific H-D allometric equations than large-scale H-D allometric equations or the allometric equations based on structural variables or a combination of structural and environmental variables.

Unfortunately, all of the above-mentioned H-D allometric equations were fitted from multi-species datasets minimizing the species effect, which is known to be significant (Fayolle et al., 2016; King, 1996; Loubota Panzou et al., 2018b; Poorter et al., 2006). Among coexisting species, tree architectural differences showed to be species-specific. Two groups of species with distinct tree architecture and adult stature are commonly distinguished, large-statured species on the one hand and small-statured species on the other hand. Large-statured species tend to be light-demanding, wind-dispersed and semi-deciduous (Loubota Panzou et al., 2018b). They have a higher adult stature and attain taller height than small-statured species, which tend to be shade-tolerant, animal-dispersed and evergreen. For a given diameter, Fayolle et al., (2016) showed that trees from semi-deciduous forests are taller and reach higher maximum height than trees in evergreen forests. Similarly, Loubota Panzou et al., (2018a) found taller trees, for a given diameter, in the Celtis forest where the canopy is dominated by light-demanding species than in the Manilkara forest where the canopy is dominated by shade-tolerant species. In tropical forests, large-statured trees are less abundant than small-statured trees (Loubota Panzou et al., 2018b). Consequently, pooling data across species as done in existing H-D allometric equations will result in an over-representation of locally abundant species. Such allometric equations will tend to show lower performance on data with a different species combination and on single species data, especially for large-statured species such as $P$. elata. Additionally, few studies have considered how site effects act together to shape H-D allometric relationship for a species. Lam et al., (2017) and Kershaw et al., (2008) used the flexibility of the mixed-effect modelling strategy to derive species-specific parameter estimates from multispecies datasets. Such modelling approaches are rare or not yet developed in the tropical Africa. This is due to the low number and reduced spatial coverage of per-species observations in current H-D databases. Using a dataset consisting of 56 to 73 per-species observations in Cameroon, Fayolle et al., (2016) found significant variations in H-D allometric relationship of three light-demanding species between evergreen and semi-deciduous forests. The three species were taller and reached higher maximum height in semi-deciduous forests. Similarly, Loubota Panzou et al., (2018a) found significant variations in H-D allometric relationship of sixteen species between a Celtis and Manilkara forests in the Republic of Congo using a dataset consisting of 12 to 58 per-species observations. Trees were taller in the Celtis forest. Nonetheless, we still lack a clear understanding of the site effect, especially in the Congo Basin forests, which remain relatively understudied (Verbeeck et al., 2011). A study by Bastin et al., $(2018,2015)$ showed that the few largest trees in the stand determine AGB at the stand level. Therefore, having good speciesspecific allometric equations for emergent species could significantly improve stand-level productivity and AGB estimates. Such single-species H-D allometric equations are particularly relevant for tropical multispecies stands where efforts have long been focused on the development of multispecies $\mathrm{H}-\mathrm{D}$ allometric equations. As an emergent and one of tallest tree species of the semi-deciduous forests of the Congo Basin, $P$. elata is a good candidate.

This study aimed at developing an H-D allometric equation for the emergent species $P$. elata. Because $P$. elata is a large-statured species, we hypothesized that existing large-scale and local multi-species H-D models would underestimate the height, compromising predictions of species productivity and AGB. Here we measured diameter, total height and trunk height of 2,288 trees of $P$. elata from different stands in the Democratic Republic of the Congo (DRC) and Cameroon. For sites in DRC, we also measured tree-level competition, light availability at the tree crown level and crown dimensions to test for their effects on the H-D allometry of $P$. elata at the local-scale where climate and stand structure show minor variation. We used this large H-D dataset to address the following specific objectives: (i) quantify and evaluate the significance of the deviations in tree height estimation from the pantropical, regional and local multi-species H-D allomteric equations. We specifically tested for the appropriateness of using multi-species H-D allometric equations to predict tree height and, therefore, estimate the productivity of P. elata; (ii) determine the theoretical function providing best $\mathrm{H}-\mathrm{D}$ fits for $P$. elata. We specifically tested the hypothesis of asymptotic height growth with a saturated height growth around the maximum stand-level 
tree height; (iii) use the selected best theoretical function to test for site effects and; in case of a significant site-specific variation, (iv) test if stand-level and environmental variables are significant predictors of this variability at the regional level (including both countries); and finally (v) evaluate the additional effect of tree-level variables at local level (DRC only).

\section{Materials and methods}

\subsection{Study species and sites}

P. elata is a long-lived light-demanding, semi-deciduous and winddispersed species (Bourland et al., 2012; de Ridder et al., 2014; Hall and Swaine, 1981). This endemic and endangered timber species has a disjunctive natural distribution area ranging from Ivory Coast to the Democratic Republic of the Congo (DRC). Easily recognized by its creamy or greyish flaky bark, its compound leaves, and its fruits, the species can reach $60 \mathrm{~m}$ height with a diameter at breast height (DBH) up to $160 \mathrm{~cm}$ (Kafuti et al., 2020). The species has a high tolerance of soil moisture content and reaches it optimum on rich phosphorus and sulphur clay soils (Bourland et al., 2012). The density of its wood ranges between 0.57 and $0.71 \mathrm{~g} \mathrm{~cm}^{-3}$. Populations of $P$. elata are decreasing allover its natural distribution range because of overexploitation, reduced natural regeneration and perhaps climate change. The last largest populations are found in the Democratic Republic of the Congo (DRC) and Cameroon where this study was conducted.

The study was conducted on four sites (Fig. 1), of which three were located in DRC, (i) Yangambi $\left(\mathrm{N} N 0^{\circ} 48^{\prime} ; \mathrm{E} 24^{\circ} 29^{\prime}\right)$, (ii) Babusoko $\left(\mathrm{N} O 0^{\circ} 18^{\prime} ; \mathrm{E}_{2} 5^{\circ} 19^{\prime}\right)$ and (iii) Biaro $\left(\mathrm{NOO}^{\circ} 15 ; \mathrm{E}^{2} 5^{\circ} 25^{\prime}\right)$ and one in Cameroon, (iv) Mindourou (N03 ${ }^{\circ} 13$; $\left.\mathrm{E} 4^{\circ} 18^{\prime}\right)$. The studied sites are characterized by semi-deciduous forests (White, 1986), but at some locations we can find moist evergreen forests, secondary forests, swamp and seasonally flooded forests and, especially in Yangambi, monodominant forests of Gilbertiodendron dewevrei (De Wild.) J. Léonard and monodominant forests of Brachystegia laurentii (De Wild.) Louis ex Hoyle.

The three DRC sites are within a maximum of $200 \mathrm{~km}$ distance from each other and share similar climatic conditions. The average annual rainfall of the region (1980-2012) is 1,839 $\pm 205.7 \mathrm{~mm}$ (Kearsley et al., 2016). According to the definition of Worbes, (1995), there are no dry months (with $<60 \mathrm{~mm}$ rainfall) in the region but January, February and June receive $<100 \mathrm{~mm}$ rainfall. Temperatures are almost constant throughout the year with a minimum of $24.2 \pm 0.4{ }^{\circ} \mathrm{C}$ in July and a maximum of $25.5 \pm 0.6^{\circ} \mathrm{C}$ in March. The climate at Mindourou is a little drier and cooler with an average annual rainfall of $1,626 \mathrm{~mm}$ and a monthly average temperature of 23.5 to $24.5^{\circ} \mathrm{C}$ (Bourland et al., 2012). The driest months of the year (January, February and June) are drier in Cameroon than in DRC but the wettest month of the year (October) receives more rainfall in Cameroon than in DRC. Studied sites in DRC and Cameroon show similar soils. They are characterized by a red or yellow ferrallitic soils with eolian sediments composed mostly of quartz sand, kaolinite and hydrated iron oxides (Bourland et al., 2012; Kearsley et al., 2016).

\subsection{Height and diameter measurements}

We measured height and diameter on 2,288 trees from different stands. In Yangambi, we selected 610 trees from an old-growth semideciduous terra-firma forest (YBI1), 189 trees from a part of the previous forest that was subjected to silvicultural operations during the period 1930-1955 (called disturbed forest of Yangambi or YBI2) and 1,040 trees from a planted population of $P$. elata (called plantation or YBI3). This population was planted in 1940 as a silvicultural enrichment within a portion of 24 ha of the old-growth semi-deciduous forest of Yangambi. All sites in Yangambi are within a $10 \mathrm{~km}$ distance from each other. In Biaro, we selected 126 trees from an old-growth semi-deciduous terra-

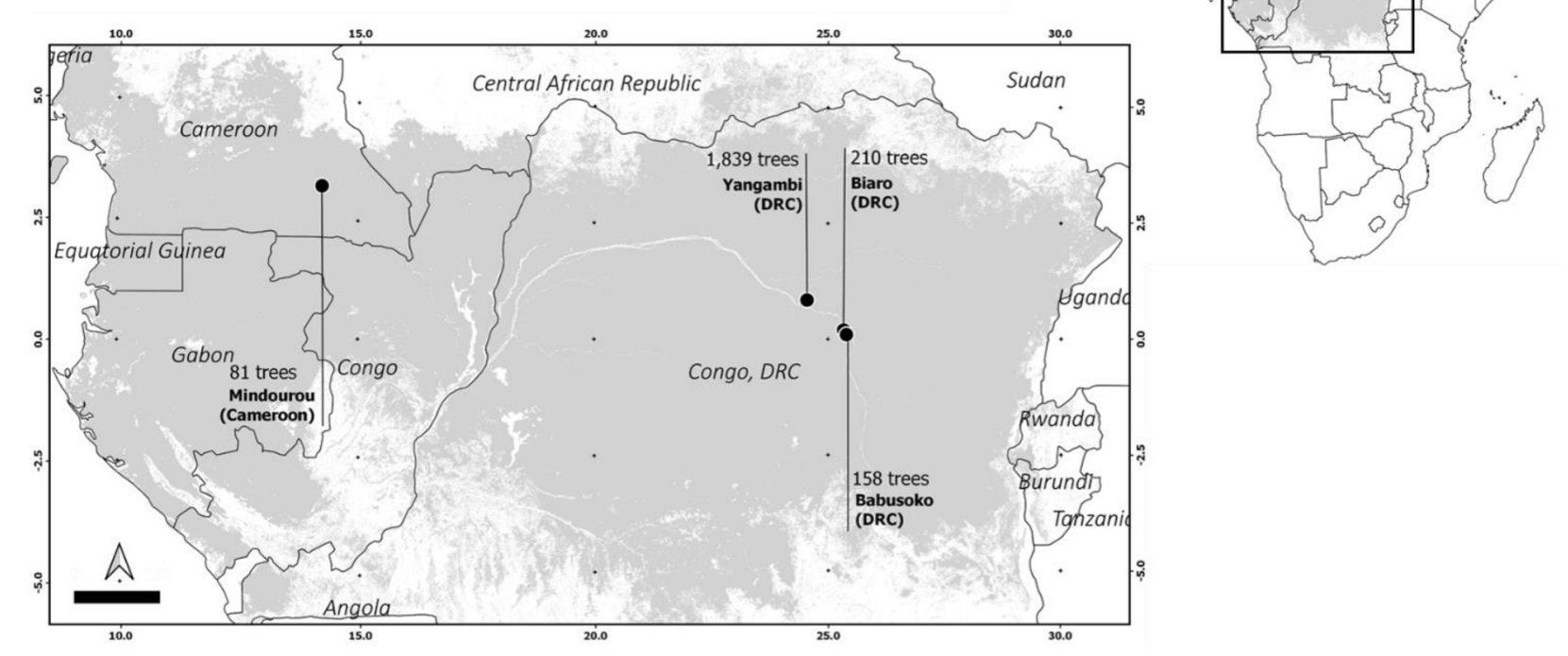

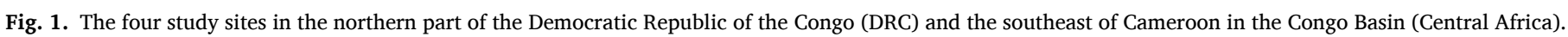

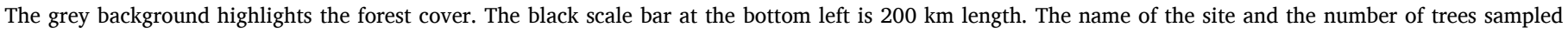
are provided. 
firma forest (BRO1) and 84 trees from a semi-deciduous forest subjected to artisanal logging (called disturbed forest of Biaro or BRO1). In Babusoko, we selected 158 trees from a seasonally flooded forest (called flooded forest of Babusoko or BSK). In Mindourou, we used data from 32 trees selected in an old-growth semi-deciduous terra-firma forest (MDR1) (see Fayolle et al., (2016)) and selected 49 trees from a portion of the previous forest having visible signs of human disturbances (MDR2).

Tree height (i.e. tree total height) and trunk height were measured using a Nikon Laser Rangefinder Forestry Pro hypsometer and, especially for trees from MDR1 in Cameroon, with a VERTEX IV dendrometer. For each standing tree, the top was identified from different view angles and the height was measured from the position providing a correct view of the top. Trees with non-visible top or with broken crown were not considered. Diameter was measured using a tape at $130 \mathrm{~cm}$ height from the ground level or $30 \mathrm{~cm}$ above the deformation. Trees with deformation at the measurement level were rare, as $P$. elata is known to have an almost cylindrical shaped trunk. For trees from the young plantations, tree height was measured using a telescopic height gauge and tree diameter was measured using a caliper. Height and diameter (H-D) measurements were then used to calculate the slenderness coefficient as the ratio of height (in meter) and diameter (in meter).

\subsection{Stand-level and environmental variables: regional-scale predictors}

At the stand level, we calculated the stem density $\left(S_{D}, h a^{-1}\right)$, basal area $\left(B A, m^{2} h a^{-1}\right)$ and average diameter $\left(D_{a v r}, c m\right)$ for trees with a DBH higher or equal to $10 \mathrm{~cm}$ and $20 \mathrm{~cm}$ respectively, in the circular plots installed (Table 1). For all these variables, the stand-level value corresponds to the average of individual values from each circular plot. For sites in Cameroon where circular plots were not installed for technical and financial reasons, we used inventory data from the logging company Pallisco (see details in Fayolle et al., (2016) and Bourland et al., (2012)) to compute the above-mentioned stand variables. To test for variations in the stand and population-level attributes, we computed a KruskalWallis rank sum test with site (stand) as random factor. In addition, we computed a redundancy analysis (RDA) using the package "BiodiversityR" (Kindt and Coe, 2005) to test for differences in species composition between the five stands in DRC. Using the geographic coordinates of each tree, we extracted values of two environmental variables from the global gridded layer of Chave et al., (2014). This global gridded layer is available online through this link: http://chave.ups-tlse. fr/pantropical_allometry.htm. The two environmental variables extracted are the environmental stress variable $(E)$ and the climatic water deficit (CWD). The variable $E$ is a compound index combining temperature seasonality, precipitation seasonality and drought intensity. It is relates to the amount of time a plant is exposed to stressful temperature. The CWD (always-negative value) corresponds to water lost by the environment during months where evapotranspiration exceeds rainfall. Sites with very negative CWD value are strongly seasonally waterstressed (Chave et al., 2014). These two variables was first used, with altitude, in the RDA to test their effect on species composition.

\subsection{Tree-level variables: local-scale predictors}

At the tree level, we estimated the level of crown illumination, the crown dimensions and the level of competition. For each site in the DRC, tree-level variables were estimated on a subset of five trees selected from each DBH class. The level of crown illumination was estimated using the original five-state classification of Dawkins and Field, (1978). This classification is based on the tree position in the canopy and the proportion of tree crown exposed to sunlight (Moravie et al., 1999). Five classes (called crown illumination index hereafter), ranging from 1 to 5 , are distinguished, a value of 1 for trees where the crown is entirely shaded vertically and laterally by other crowns; a value of 2 for trees
Table 1

Characteristics (number of plots, $n$; stem density, $S_{D 10}$ and $S_{D 20}$; basal area, $B A_{10}$ and $B A_{20}$; average diameter, $D_{\text {avr } 10}$ and $D_{\text {avr } 20}$ for trees with dbh larger than or equal to $10 \mathrm{~cm}$ and $20 \mathrm{~cm}$ respectively; maximum diameter of trees, $D_{\max }$; average dimeter of trees of P. elata, $D_{a v r}$; average total height of trees of P. elata, $H_{T O T}$; average height to the first branch of trees of $P$. elata, $H_{F B}$; average crown depth of trees of P. elata, $C_{D}$; number of species observed, $S_{o b s}$; Shannon-Weaver index, $H$; and Simpson index, $D$; environmental stress factor, $E$; climatic water deficit, $C W D$ ) of the five stands located in a non-planted forest in DRC. Considered stands include an old-growth semi-deciduous terra-firma forest in Yangambi (YBI1), a disturbed semi-deciduous forest in Yangambi (YBI2), an oldgrowth semi-deciduous terra-firma forest in Biaro (BRO1), a disturbed semideciduous terra-firma forest in Biaro (BRO2) and a seasonally flooded forest in Babusoko (BSK). Each stand characteristic is provided with its standard error. Letters next to each value represent the result of the Kruskal-Wallis rank sum test with the same letter expressing no significant differences between considered sites.

\begin{tabular}{|c|c|c|c|c|c|c|}
\hline & YBI1 & YBI2 & BRO1 & BRO2 & BSK & $\begin{array}{l}P \text { - } \\
\text { value }\end{array}$ \\
\hline \multicolumn{7}{|c|}{ Stand-level structure } \\
\hline$n[p l o t s]$ & 50 & 50 & 50 & 48 & 47 & $N A$ \\
\hline$S_{D 10}\left[h a^{-1}\right]$ & $\begin{array}{l}430.5 \pm \\
60.4 a\end{array}$ & $\begin{array}{l}447.5 \pm \\
52.8 a\end{array}$ & $\begin{array}{l}364.0 \pm \\
81.4 b\end{array}$ & $\begin{array}{l}368.4 \pm \\
65.7 b\end{array}$ & $\begin{array}{l}337.7 \pm \\
68.9 b\end{array}$ & $* * *$ \\
\hline$S_{D 20}\left[h a^{-1}\right]$ & $\begin{array}{l}217.0 \pm \\
42.7 a\end{array}$ & $\begin{array}{l}213.7 \pm \\
28.7 a\end{array}$ & $\begin{array}{l}159.4 \pm \\
40.9 b\end{array}$ & $\begin{array}{l}160.1 \pm \\
42.6 b\end{array}$ & $\begin{array}{l}129.7 \pm \\
39.2 c\end{array}$ & $* * *$ \\
\hline $\begin{array}{l}B A_{10}[ \\
\left.\quad m^{2} h a^{-1}\right]\end{array}$ & $\begin{array}{l}33.1 \pm \\
6.4 a\end{array}$ & $\begin{array}{l}33.5 \pm \\
7.5 a\end{array}$ & $\begin{array}{l}28.5 \pm \\
8.4 b\end{array}$ & $\begin{array}{l}30.5 \pm \\
8.9 a b\end{array}$ & $\begin{array}{l}23.0 \pm \\
7.9 c\end{array}$ & $* * *$ \\
\hline $\begin{array}{l}B A_{20}[ \\
\left.\quad m^{2} h a^{-1}\right]\end{array}$ & $\begin{array}{l}29.6 \pm \\
6.3 a\end{array}$ & $\begin{array}{l}29.6 \pm \\
7.6 a\end{array}$ & $\begin{array}{l}25.2 \pm \\
8.2 b\end{array}$ & $\begin{array}{l}27.2 \pm \\
9.0 a b\end{array}$ & $\begin{array}{l}19.8 \pm \\
7.9 c\end{array}$ & $* * *$ \\
\hline$D_{\text {avr } 10}[\mathrm{~cm}]$ & $\begin{array}{l}26.1 \pm \\
2.0 a\end{array}$ & $\begin{array}{l}25.7 \pm \\
2.4 a\end{array}$ & $\begin{array}{l}25.2 \pm \\
2.6 a b\end{array}$ & $\begin{array}{l}25.9 \pm \\
3.7 a\end{array}$ & $\begin{array}{l}23.6 \pm \\
3.5 b\end{array}$ & $* * *$ \\
\hline$D_{\text {avr } 20}[\mathrm{~cm}]$ & $\begin{array}{l}38.0 \pm \\
3.3 b\end{array}$ & $\begin{array}{l}38.1 \pm \\
3.5 b\end{array}$ & $\begin{array}{l}39.7 \pm \\
4.3 a b\end{array}$ & $\begin{array}{l}41.3 \pm \\
4.4 a\end{array}$ & $\begin{array}{l}39.1 \pm \\
5.0 a b\end{array}$ & $* * *$ \\
\hline$D_{\max }[\mathrm{cm}]$ & $\begin{array}{l}88.9 \pm \\
22.3 a b c\end{array}$ & $\begin{array}{l}87.8 \pm \\
23.5 b c\end{array}$ & $\begin{array}{l}95.4 \pm \\
16.6 a\end{array}$ & $\begin{array}{l}95.0 \pm \\
16.8 a b\end{array}$ & $\begin{array}{l}84.1 \pm \\
23.5 c\end{array}$ & $* * *$ \\
\hline \multicolumn{7}{|c|}{ Population-level structure } \\
\hline$D_{a v r}[\mathrm{~cm}]$ & $\begin{array}{l}66.8 \pm \\
29.3 a\end{array}$ & $\begin{array}{l}62.7 \pm \\
24.4 a\end{array}$ & $\begin{array}{l}63.7 \pm \\
28.4 a\end{array}$ & $\begin{array}{l}69.4 \pm \\
31.9 a\end{array}$ & $\begin{array}{l}58.6 \pm \\
33.9 a\end{array}$ & $n s$ \\
\hline$H_{T O T}[m]$ & $\begin{array}{l}39.6 \pm \\
9.7 a b\end{array}$ & $\begin{array}{l}43.0 \pm \\
8.1 a\end{array}$ & $\begin{array}{l}36.4 \pm \\
8.2 b\end{array}$ & $\begin{array}{l}38.7 \pm \\
9.0 a b\end{array}$ & $\begin{array}{l}36.2 \pm \\
9.8 b\end{array}$ & $* *$ \\
\hline$H_{F B}[m]$ & $\begin{array}{l}20.0 \pm \\
6.3 a\end{array}$ & $\begin{array}{l}21.2 \pm \\
4.9 a\end{array}$ & $\begin{array}{l}20.1 \pm \\
5.9 a\end{array}$ & $\begin{array}{l}18.1 \pm \\
6.8 a\end{array}$ & $\begin{array}{l}19.1 \pm \\
5.9 a\end{array}$ & $n s$ \\
\hline$C_{D}[m]$ & $\begin{array}{l}19.6 \pm \\
9.1 a b\end{array}$ & $\begin{array}{l}21.8 \pm \\
7.4 a\end{array}$ & $\begin{array}{l}16.2 \pm \\
7.5 b\end{array}$ & $\begin{array}{l}20.6 \pm \\
10.1 a b\end{array}$ & $\begin{array}{l}17.1 \pm \\
7.9 a b\end{array}$ & $* *$ \\
\hline \multicolumn{7}{|l|}{ Diversity } \\
\hline$S_{o b s}$ & $\begin{array}{l}25.5 \pm \\
4.0 c\end{array}$ & $\begin{array}{l}26.1 \pm \\
3.7 c\end{array}$ & $\begin{array}{l}29.1 \pm \\
5.5 a b\end{array}$ & $\begin{array}{l}30.0 \pm \\
4.8 a\end{array}$ & $\begin{array}{l}26.4 \pm \\
5.0 b c\end{array}$ & $* * *$ \\
\hline$H$ & $\begin{array}{l}2.89 \pm \\
0.27 c\end{array}$ & $\begin{array}{l}2.89 \pm \\
0.25 c\end{array}$ & $\begin{array}{l}3.18 \pm \\
0.25 a\end{array}$ & $\begin{array}{l}3.23 \pm \\
0.19 a\end{array}$ & $\begin{array}{l}3.05 \pm \\
0.27 b\end{array}$ & $* * *$ \\
\hline$D$ & $\begin{array}{l}0.92 \pm \\
0.04 c\end{array}$ & $\begin{array}{l}0.91 \pm \\
0.04 c\end{array}$ & $\begin{array}{l}0.95 \pm \\
0.02 a\end{array}$ & $\begin{array}{l}0.95 \pm \\
0.01 a\end{array}$ & $\begin{array}{l}0.94 \pm \\
0.03 b\end{array}$ & $* * *$ \\
\hline \multicolumn{7}{|c|}{ Environment } \\
\hline$E$ & $\begin{array}{l}-0.053 \\
\pm \\
0.0005 e\end{array}$ & $\begin{array}{l}-0.050 \\
\pm \\
0.0004 d\end{array}$ & $\begin{array}{l}-0.042 \\
\pm \\
0.0004 b\end{array}$ & $\begin{array}{l}-0.041 \\
\pm \\
0.0004 a\end{array}$ & $\begin{array}{l}-0.044 \\
\pm \\
0.0005 c\end{array}$ & $* * *$ \\
\hline$C W D$ & $\begin{array}{l}-70.27 \\
\pm \\
0.049 e\end{array}$ & $\begin{array}{l}-70.26 \\
\pm \\
0.023 d\end{array}$ & $\begin{array}{l}-55.87 \\
\pm \\
0.178 c\end{array}$ & $\begin{array}{l}-52.56 \\
\pm \\
0.173 b\end{array}$ & $\begin{array}{l}-48.95 \\
\pm \\
0.615 a\end{array}$ & $* * *$ \\
\hline
\end{tabular}

$* * *, * *, *$ and $n s$ are significant codes: 0 ‘**' 0.001 ***, 0.01 ‘*’ 0.05 'ns.

where the crown is entirely shaded vertically and receives some direct side light; a value of 3 for trees where the crown receives some overhead light and any side light; a value of 4 for trees where the crown is entirely exposed to vertical light with some lateral light; and a value of 5 for trees where the crown receives full vertical and lateral light. The crown illumination index was attributed to 1,906 trees randomly selected among trees with H-D measurements from sites in DRC. For each tree, the crown illumination index was attributed by visual observation of the tree crown.

Four crown dimensions were measured, crown depth $\left(C_{D}, m\right)$, crown radius $\left(C_{R}, m\right)$, crown projection area $\left(C_{A}, m^{2}\right)$ and crown volume $\left(C_{V}\right.$, 
$\mathrm{m}^{3}$ ). Crown depth was calculated as the difference between the total tree height and the height to the crown base (Hasenauer and Monserud, 1996; Loubota Panzou et al., 2021). Crown radius was calculated as the quadratic average of crown radii measured in eight sub-cardinal directions (North, Northwest, West, Southwest, South, Southeast, East and Northeast). Crown radius in a specific direction was measured as the distance from the center of the trunk to the perimeter of the crown using the vertical sighting method (Preuhsler, 1981). Crown projection area was calculated from crown radius using the following formula: $C_{A}=$ $C_{R}{ }^{2 *} \pi$ (Pretzsch et al., 2015). Crown volume was calculated from crown depth and crown radius as $C_{V}=(2 / 3) * \pi^{*} C_{R}{ }^{2 *} C_{D}$.

To estimate the level of competition, we installed a circular plot of $20 \mathrm{~m}$ radius (corresponding to $0.126 \mathrm{ha}$ ), around each tree. Within each circular plot, we inventoried all trees with a DBH larger than or equal to $10 \mathrm{~cm}$ (called neighbour). For each neighbour, the botanical name of the species was recorded. In addition, the diameter at the breast height (DBH) and the polar coordinates was measured. The DBH was measured using a tape at $130 \mathrm{~cm}$ height from the ground level or $30 \mathrm{~cm}$ above the deformation. The polar coordinates include the distance and the azimuth of the neighbour from the focal tree. Twelve competition indices (Table S1) were calculated using the inventory data from each circular plot. To select a relevant competition index to be used as predictor in further models, we computed pairwise Pearson rank correlation (Fig. S1). The competition index of Rouvinen and Kuuluvainen, (1997) (sdrAng), which was the most correlated with the maximum of other competition indices, was selected for further analysis.

\subsection{Height-diameter models}

We first compared our height observations with seven existing H-D models (Table S2), (i) a pantropical model (Chave et al., 2014), (ii) a regional model for Africa (Banin et al., 2012), (iii) a regional model for tropical Africa (Lewis et al., 2009), (iv) two regional models for Central Africa (Feldpausch et al., 2012, 2011), (v) a regional model for the Eastern Congo Basin and East Africa (Hubau et al., 2020) and (vi) a local model for Yangambi in DRC (Kearsley et al., 2013). The errors in height estimates from these models was quantified using the root mean squared error (RMSE). Fitted model parameters are presented in Table S3. The significance of the differences between our observed height and the height predicted by the models was tested using a paired $t$-test. A residuals analysis was then performed and graphically illustrated using the function 'mywhiskers' from the R package "Imfor" (Mehtatalo, 2020). We plotted the means of residuals in 10 classes of tree diameter together with the $95 \%$ confidence interval for the class mean. The 10 classes of diameter were automatically created by the function 'mywhiskers' in a way allowing each class to have approximately the same number of observations.

To select the best H-D model for P. elata, we fitted and compared seven commonly used theoretical functions (Table S4). Fitted theoretical functions include the power model ( $m 1$ ) (Feldpausch et al., 2011), the two-parameter exponential model (m2) (Meyer, 1940), the threeparameter exponential model (m3) (Banin et al., 2012), the Gompertz model (m4) (Feldpausch et al., 2012), the Weibull model (m5) (Feldpausch et al., 2012; Zhang et al., 2020), the Michaelis-Menten model (m6) (Molto et al., 2014) and the logistic model (m7) (Richards, 1959). All the models were computed using the function ' $d r m$ ' of the R package "drc" (Ritz et al., 2015). The best model was selected based on the Akaike Information Criterion (AIC) and the Residual Standard Error (RSE). Although all the tested theoretical functions tended to provide best fits at one or multiple sites, the three-parameter exponential function (m3) which showed best fits at the species level (Table S5) was selected for further analysis.

$H=a+(b-a)^{*}\left[\left(1-\exp \left(-c^{*} D\right)\right]\right.$

The three-parameter exponential function (Eq. 1) was then used to test for site-specific variations in H-D allometry of $P$. elata. In this model, the parameter $a$ represents the upper limit, corresponding to the maximum asymptotic height $\left(H_{\max }\right.$, in $\left.\mathrm{m}\right)$, the parameter $b$ represents the lower limit, corresponding to the tree height at $0 \mathrm{~cm}$ diameter and the parameter $c$ represents the logarithm of the rate constant, corresponding to the steepness of the increase in tree height $(H, \mathrm{~m})$ with diameter $(D, \mathrm{~cm})$. A mixed-effect version of this model with site introduced as random effect was fitted (site-specific NLME hereafter) using the 'nlme' function of the R package "nlme" (Pinheiro et al., 2019). A significant site-specific variation in H-D allometry of $P$. elata was identified. We tested the random structure by keeping the fixed effects structure constant and applying different combinations of random effects to the model parameters (Pinheiro and Bates, 2000). The fixed effects $a, b$ and $c$ represent the mean values of the parameters in the population of individuals. Based on AIC and RSE values, the model with invariant parameter $b$ and site-specific parameters $a$ and $c$ showed better fits (Eq. 2). However, because of the higher correlation between the parameter $a$ and $c$, we fitted a new model with invariant parameters $b$ and $c$ (Eq.3) and compared this model with the model in Eq.2 using ANOVA test. The two models showed no significant differences $(P=$ 0.096). Therefore, the model invariant parameters $b$ and $c$ and sitespecific parameter was selected for further analysis. For this model, the parameter $a$ in Eq. 1 is replaced by $a=a+a 1_{i}$. The corresponding model is called site-specific NLME hereafter. With $a$ standing for the asymptotic maximum height and $a 1$ the site deviation. The errors are normally distributed and are independent of the random effects

To test for the effect of stand-level and environmental variables as potential drivers of this site-specific variation in the H-D allometric relationship of $P$. elata, we included stand-level and environmental variables as covariates in the site-specific NLME. As stand-level variables, we used the stem density and basal area of trees with DBH higher or equal to $20 \mathrm{~cm}$. Two climatic indices were used as environmental variables, the stress variable $(E)$ and the climatic water deficit (CWD). The covariates were tested as being linearly related to the parameter $a$. A stepwise model-building approach was used to select the best covariates to be used in the final model (Pinheiro and Bates, 2000). The goodness of the fitted models was assessed using AIC and RMSE. The same modelling approach was used to test for the effect of tree-level variables as potential drivers of local-scale variation in H-D allometric relationship of $P$. elata. For this analysis, we used tree-level variables as covariates. During this stepwise procedure, the tree-level light availability and the crown depth showed to be the useful covariates $(P<0.001)$. Three derivative models were therefore fitted, (i) a model with light availability only as covariate (extended NLME 1 ) where parameter $a$ is replaced by $a=\left(a+a 1_{i}\right)+\left(d^{*}\right.$ Dawkins $)$; (ii) a model with crown depth only as covariate (extended NLME 2 ) where parameter $a$ is replaced by $a=\left(a+a 1_{i}\right)+\left(e^{*} C_{D}\right)$ and, (iii) a model with both light availability and crown depth as covariates (extended NLME 3 ) where parameter $a$ is replaced by $\left(a+a 1_{i}\right)+\left(d^{*}\right.$ Dawkins $)+\left(e^{*} C_{D}\right)$. We restricted this analysis to the 245 trees with tree-level variables measured.

\section{Results}

\subsection{Performance of existing $H-D$ models}

Existing H-D models underestimate the total height of $P$. elata in most sites (Fig. 2 and Table S3) as the Mean Signed Deviation is significantly negative ( $\mathrm{p}<0.001$ ). The local multispecies H-D model of Yangambi developed by Kearsley et al., (2013) showed the highest underestimation in all the studied sites (Table S3). At the species level, the residual analysis (Fig. 2) showed that the regional model of Lewis et al., (2009) for tropical Africa performs well $(P=0.069)$. The regional model of Feldpausch et al., (2012) for central Africa tends to predict the total height of trees with DBH smaller than $50 \mathrm{~cm}$ relatively well. At the sites level (Table S3), we found that this model best predicts the total height in the disturbed forest of Biaro $(P=0.216)$ and the flooded forest of 

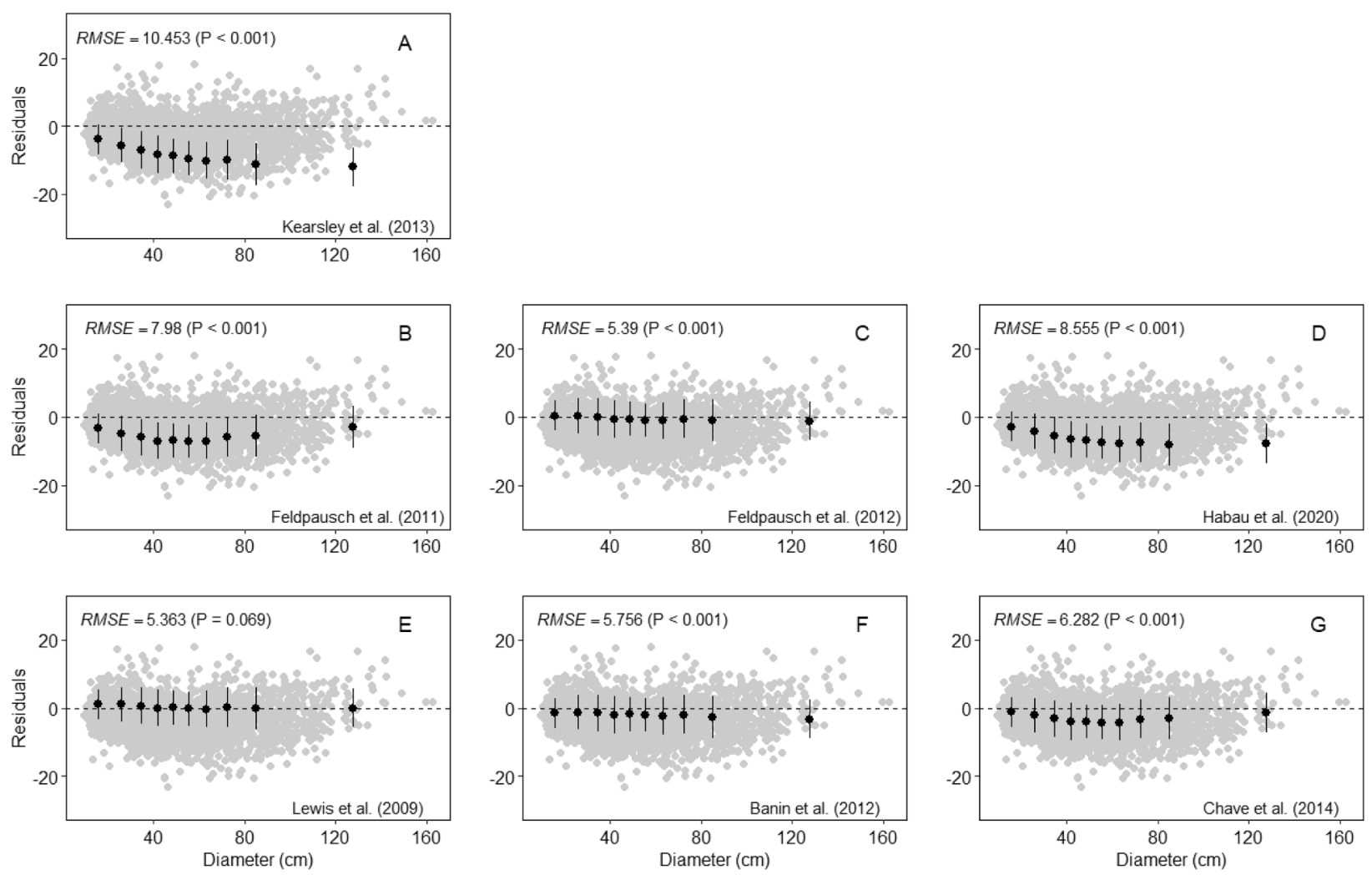

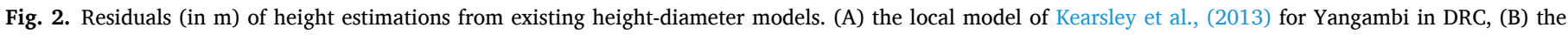

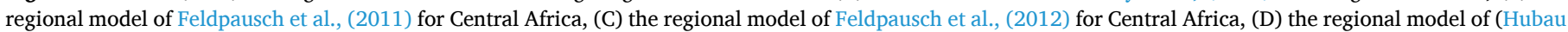

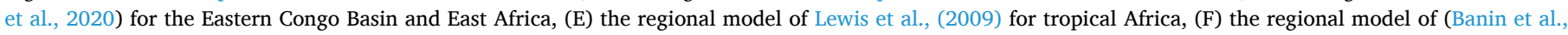

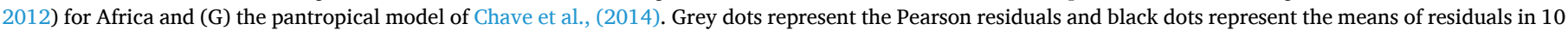

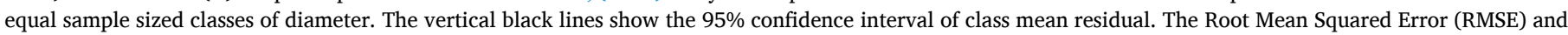
the p-value of test of significance differences between observed height and the height predicted by the existing H-D models are also provided.

Babusoko $(P=0.375)$ but underestimates it in the natural forest of Yangambi $(P \leq 0.001)$ and overestimates it in Mindourou $(P<0.001)$. In this latter site, the pantropical model developed by Chave et al., (2014) and the regional model developed by Feldpausch (Feldpausch et al., 2012 , 2011) better predict the total height of $P$. elata $(P=0.234$ for MDR1 and $P=0.342$ for MDR2).

\subsection{Development of H-D models for P. Elata}

The seven tested nonlinear theoretical functions fitted to the H-D data of P. elata quite well (Fig. 3 and Table S5). We found a clear saturation of tree height with diameter for $P$. elata, suggesting that the species height growth is not continuous but reach an asymptote when the maximum height is attained. A best predictive ability was obtained from asymptotic functions compared to the power function, which showed the poorest fits. The two-parameter exponential model showed better fits (lower AIC and RSE) for trees from the disturbed forests (YBI2, $\mathrm{BRO} 2$ and MDR2). The logistic model performs better for trees from the plantation and from the flooded forest of Babusoko. The MichaelisMenten model performs better for trees from undisturbed forests (YBI1, BRO1 and MDR1). At the species level, the three-parameter exponential model was the overall best performing model. Predictions of this model do not differ with predictions of the best site-specific model. Despite the best performance of the species-level NLM at the species level, this model underestimates tree height for sites in the undisturbed and disturbed forests of the DRC and overestimates tree height for similar sites in Cameroon (Table 2). This result supports the need for a site-specific H-D allometric equation for P. elata.

Using the mixed-effects version of the three-parameter exponential model, we found lower AIC and RSE from the models with random effects on site and habitat, suggesting a significant between-site and between-habitat variations in H-D allometric relationship of $P$. elata (Table 2). These variations showed to be associated with differences in the maximum asymptotic height (parameter $a$ ). Based on the best sitespecific model, we found that trees tend to be taller in DRC than in Cameroon. The $H_{\max }$ was 49.21 [46.98-51.44] $\mathrm{m}$ for the undisturbed and 48.55 [46.77-50.33] $\mathrm{m}$ for the disturbed forest of Yangambi; 46.96 [39.94-53.97] $\mathrm{m}$ for the undisturbed and 43.53 [41.09-45.97] $\mathrm{m}$ for the disturbed forest of Biaro in DRC and 43.82 [35.16-52.49] $\mathrm{m}$ for the undisturbed and 39.97 [38.46-41.48] $\mathrm{m}$ for the disturbed forest of Mindourou in Cameroon. Planted and seasonally flooded forests showed lower $H_{\max }$ than old-growth semi-deciduous terra-firma forests with respectively 43.99 [41.24-46.73] $\mathrm{m}$ and 43.48 [42.16-44.79] $\mathrm{m}$. Whilst deviations in tree height estimation from existing multispecies models showed to be significant in most sites, the site-specific mixed-effect H-D model developed in this study showed no significant $(P>0.05)$ deviations for trees from all the studied sites (Table 2).

\subsection{Drivers of local-scale variation in H-D allometry of P. Elata}

The different studied sites in DRC showed some differences in stand structure (Table 1 ) and species composition $(P<0.001)$ (Fig. 4). The first RDA axis distinguished higher altitude sites (YBI1 and YBI2) from lower altitude sites (BRO1, BRO2 and BSK). The former sites are characterized by lower values of environmental stress factor and climatic water deficit, suggesting higher level of water deficit. In terms of species, they are characterized by higher abundance of Scorodophloeus zenkeri Harms while the other sites are characterized by higher abundance of Julbernardia seretii (De Wild.) Troupin and Aidia micrantha (K. Schum.) F. White. The second RDA axis distinguished the disturbed sites, with 

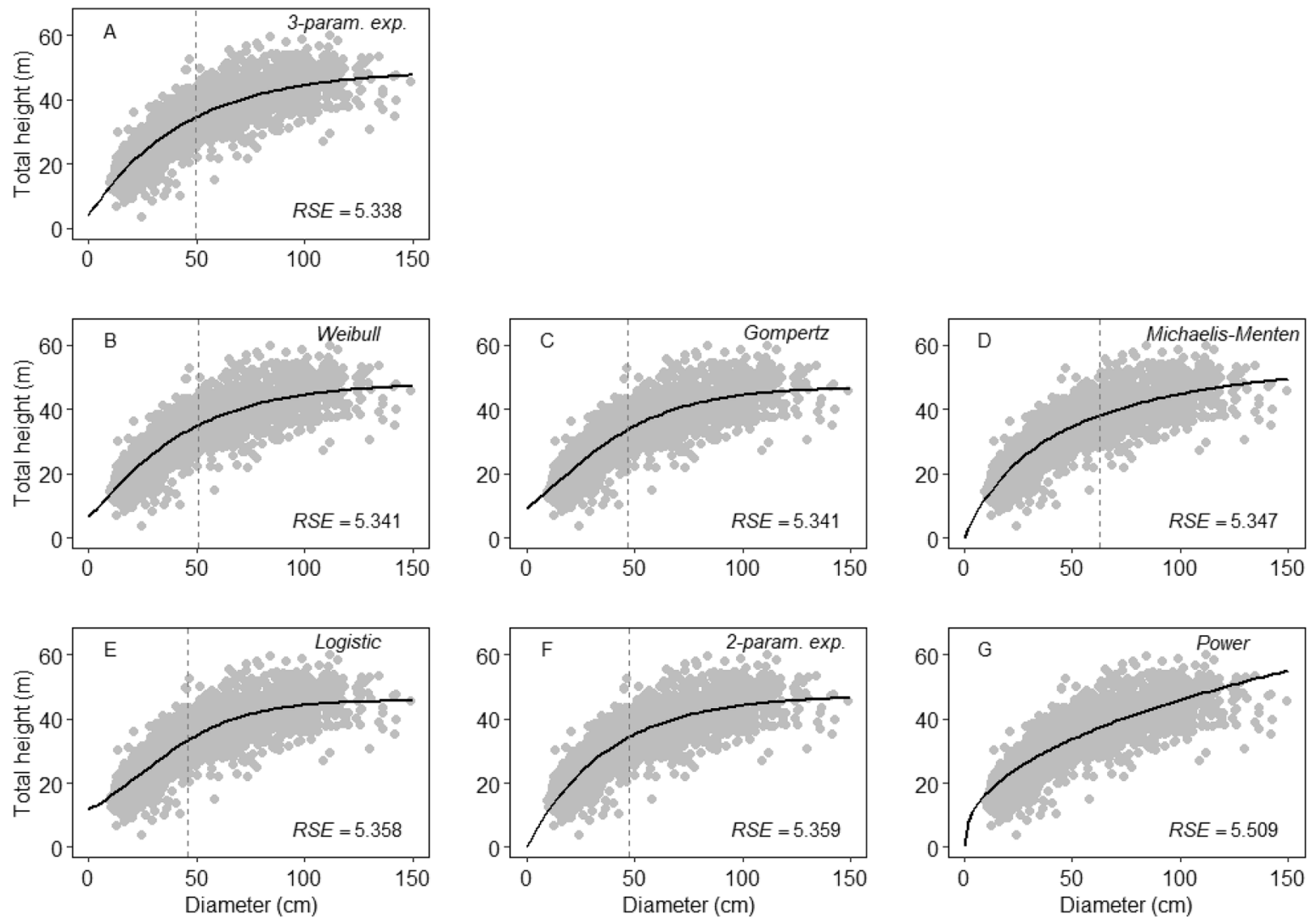

Fig. 3. Performance of the seven theoretial functions used to derive the height-diameter models for Pericopsis elata in DRC and Cameroon. The model curve (black curve) and the name of the model are provided in the plot. The gray vertical dashed line shows the half-life of the fitted curve, expressing the diameter at which trees reach half of the maximum asymptotic height.

Table 2

Parameter estimates and goodness of fit of the three-parameter exponential model $\left(H=a+(b-a) *\left[\left(1-\exp \left(-c^{*} D\right)\right]\right)\right.$ of $P$. elata in DRC and Cameroon. The model parameters ( $a, b$ and $c$ ), the Akaike Information Criterion (AIC) and the Residual Standard Error (RSE) of each model are provided. For mixed effect models (NLME) testing for site-specific and habitat-specific variations, deviations $(\alpha, \beta$ and $\gamma)$ at the site and habitat levels are also provided.

\begin{tabular}{|c|c|c|c|c|c|c|}
\hline & & \multicolumn{3}{|c|}{ Model parameters } & \multirow[t]{2}{*}{ RSE } & \multirow[t]{2}{*}{ AIC } \\
\hline & & $\mathrm{a}$ & $\mathrm{b}$ & $\mathrm{c}$ & & \\
\hline \multicolumn{2}{|l|}{ Speciesmodel } & $\begin{array}{l}49.20 \\
(0.70)\end{array}$ & $\begin{array}{l}4.14 \\
(0.89)\end{array}$ & $\begin{array}{l}-3.78 \\
(0.05)\end{array}$ & 5.337 & 14161.75 \\
\hline \multirow[t]{10}{*}{$\begin{array}{l}\text { Site-specific } \\
\text { NLME }\end{array}$} & Fixed & $\begin{array}{l}45.06 \\
(1.13)\end{array}$ & $\begin{array}{l}0.56 \\
(1.04)\end{array}$ & $\begin{array}{l}-3.49 \\
(0.04)\end{array}$ & 4.984 & 13890.05 \\
\hline & Random & $\alpha$ & $\beta$ & $\gamma$ & & \\
\hline & $\begin{array}{l}Y B I 1(n \\
=610)\end{array}$ & 2.591 & - & & & \\
\hline & $\begin{array}{l}Y B I 2(n \\
=189)\end{array}$ & 4.859 & - & & & \\
\hline & $\begin{array}{l}Y B I 3(n \\
=1040)\end{array}$ & -2.577 & - & & & \\
\hline & $\begin{array}{l}\text { BRO1 (n } \\
=126)\end{array}$ & -1.336 & - & & & \\
\hline & $\begin{array}{l}\text { BRO2 (n } \\
=84)\end{array}$ & 1.411 & - & & & \\
\hline & $\begin{array}{l}B S K(n \\
=158)\end{array}$ & 0.939 & - & & & \\
\hline & $\begin{array}{l}\text { MDR1 } \\
(n=32)\end{array}$ & -4.445 & - & & & \\
\hline & $\begin{array}{l}\text { MDR2 } \\
(n=49)\end{array}$ & -1.442 & - & & & \\
\hline
\end{tabular}

higher stem density and competition (YBI2 and BRO2) from undisturbed sites, with relatively lower stem density and competition (YBI1, BRO1 and BSK). The former sites are characterized by higher abundance of Trilepisium madasgariense DC., which is a species relatively rare in the undisturbed forests. The competition variable also showed to be positively related to the first RDA axis, allowing distinguishing YBI1 and YBI2 with higher competition levels from BRO1, BRO2 and BSK with lower competition levels.

Despite this variation in species composition seemingly driven by climate, competition and altitude, none of these variables showed to be a useful covariate accounting for the site effect. At the regional-scale, stand-level basal area showed to be an important covariate $(P<$ 0.001 ) accounting for the site effects. The inclusion of this variation in the site-specific NLME leads to a significant improvement of the model and a significant reduction of the variance explained by the site effect. The intergroup variance decreased from 2.88 [1.71-4.85] to 1.81 [1.05-3.11], corresponding to a reduction of $37 \%$ of the site-to-site variation in $H_{\max }$. At the local-scale, stand-level (basal area) or climate variables showed to be insignificant covariates. Two tree-level variables showed higher performance as covariates in the $\mathrm{H}$-D allometric equation of $P$. elata, light availability and crown depth. The model including both variables as covariates showed best performance (Table 3). The inclusion of both variables reduced the intergroup variance from 2.47 [1.23-4.97] to 1.21 [0.53-2.77], corresponding to a reduction of $51 \%$ of the site-to-site variation in $H_{\max }$ (Table 3 ). 


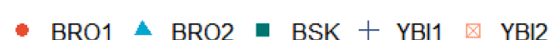

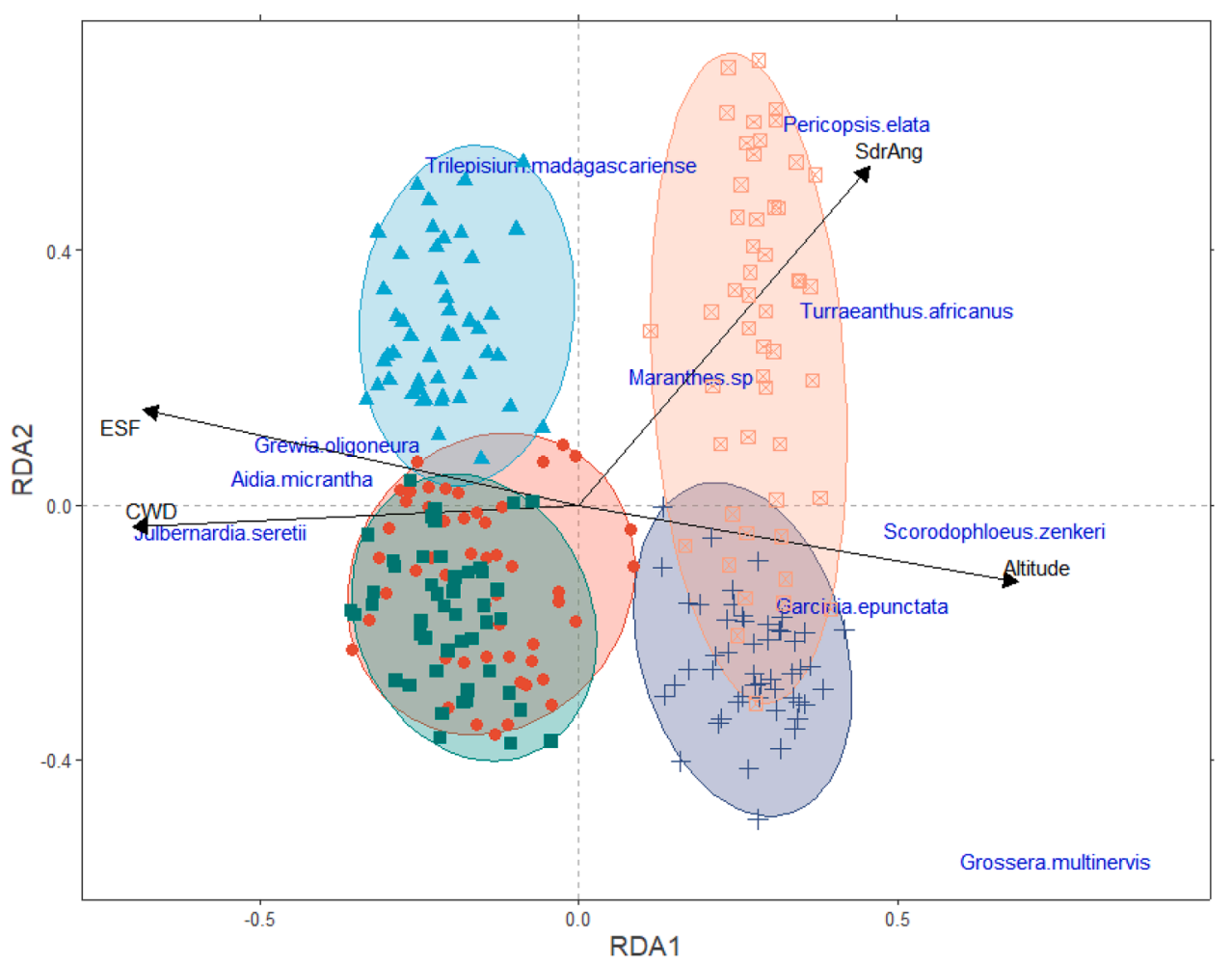

Fig. 4. Ordination diagram of the species composition in the five stands located in a nonplanted forest in DRC. Differences in species composition between the five sites are mainly driven by the ten species presented in blue. The environmental variables included in the Redundancy analysis (RDA) are represented in black segments (the environmental stress factor, ESF similar with $E$ in the text; the climatic water deficit, $C W D$; the competition index, SdrAng and the altitude). The five studied sites include an old-growth semi-deciduous forest of Yangambi (YBI1), a disturbed forest of Yangambi (YBI2), an old-growth semi-deciduous forest of Biaro (BRO1), a disturbed forest of Biaro (BRO2) and a seasonally flooded forest of Babusoko (BSK). (For interpretation of the references to colour in this figure legend, the reader is referred to the web version of this article.)

Table 3

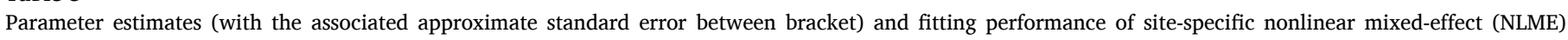
compared to the local NLME including the light availability index (Dawkins), crown depth and both variables as covariates.

\begin{tabular}{|c|c|c|c|c|c|}
\hline & Parameter & $\begin{array}{l}\text { Site-specific } \\
\text { NLME }\end{array}$ & $\begin{array}{l}\text { Site-specific local NLME with } \\
\text { Dawkins }\end{array}$ & $\begin{array}{l}\text { Site-specific local NLME with } \\
\text { crown depth }\end{array}$ & $\begin{array}{l}\text { Site-specific local NLME with Dawkins and } \\
\text { crown depth }\end{array}$ \\
\hline \multirow[t]{5}{*}{ Fixed parameters } & $\mathrm{a}$ & $49.16(1.62)$ & $39.31(2.45)$ & $37.97(1.80)$ & $29.45(2.16)$ \\
\hline & $\mathrm{b}$ & 2.56 (3.09) & $4.17(3.20)$ & $0.50(3.65)$ & $1.11(4.22)$ \\
\hline & $\mathrm{c}$ & $-3.57(0.11)$ & $-3.41(0.12)$ & $-3.22(0.12)$ & $-3.00(0.14)$ \\
\hline & $\mathrm{d}$ & - & $1.82(0.41)$ & - & $1.71(0.34)$ \\
\hline & $\mathrm{e}$ & - & - & $0.35(0.05)$ & $0.34(0.05)$ \\
\hline \multirow{2}{*}{$\begin{array}{l}\text { Variance } \\
\text { components }\end{array}$} & $\sigma^{2}$ & $4.30(0.21)$ & $4.14(0.20)$ & $3.96(0.19)$ & $3.78(0.18)$ \\
\hline & $\sigma(\mathrm{a} 1)$ & $2.47(0.81)$ & $1.98(0.65)$ & $1.65(0.20)$ & $1.21(0.19)$ \\
\hline \multirow[t]{2}{*}{ Goodness of fit } & AIC & 1241.3 & 1226.3 & 1206.6 & 1186.9 \\
\hline & RMSE & 4.253 & 4.099 & 3.921 & 3.743 \\
\hline
\end{tabular}

\section{Discussion}

\subsection{Existing multi-species $H-D$ allometric equations are inappropriate for P. Elata}

Our results showed that the use of existing multi-species H-D allometric equations on $P$. elata trees leads to significant underestimation of tree height (Fig. 2 \& Table S4). The observed deviations may be attributed to the species pool used in the existing H-D allometric equations more than environmental variations. As a large-statured and longlived light-demanding species, the growth strategy of $P$. elata allows trees of this species to grow taller for the same diameter compared to other tropical species (King, 1996; Poorter et al., 2006). However, species of this functional group are less abundant in most tropical forests (Loubota Panzou et al., 2018b). They are therefore under-represented in global datasets. A study using hierarchical models in which variations in allometric parameters are analyzed with respect to the species traits (Cano et al., 2019), showed that the interspecific variations in H-D allometric equation are substantially explained by the species sapling growth rate. Their results showed that fast-growing species are able to attain taller heights at small diameters. However, they reach shorter asymptotic heights compared to slow-growing species. Contrary to this finding, Loubota Panzou et al., (2018b) showed that large-statured species are taller than small-statured species all over the diameter range. They showed that large-statured trees tend to be light demanding, semi-deciduous and grow faster than small-statured species. Based on these results, it is not surprising that existing H-D allometric equations underestimate tree height of the large-statured light-demanding species $P$. elata. As reported in almost all previous studies testing the performance of existing H-D allometric equations, we found the highest underestimation in large diameter classes. Since the canopy of many tropical forests is dominated by light-demanding species (Vleminckx et al., 2014), the high deviations observed for large diameter trees in pooled species analysis could be translated into a lower performance of existing H-D allometric equations for light-demanding species in general. 


\subsection{Theoretical allometric functions converge at the habitat level}

One of the challenges in H-D modelling is the choice of allometric function to use. As reported in previous studies (Fayolle et al., 2016), we found that the different allometric functions provided different parameter estimates (Table S3). The maximum height (parameter $a$ in asymptotic functions) is higher in the Michaelis-Menten function. These differences in parameter estimates between different allometric functions may potentially introduce bias. Such varying allometric functions at the site or habitat level have been previously reported in Africa using pooled species approaches. In Cameroon, Fayolle et al., (2016) identified the Michaelis-Menten function as the most likely function for the semi-deciduous forest and the second order polynomial of the power function for the evergreen forest. In the montane forests of DRC, Imani et al., (2017) found the Gompertz function as the best function for sub montane (1250 to $1500 \mathrm{~m}$ asl) and lower montane (1500 to $1800 \mathrm{~m}$ asl), the Richards asymptotic function for middle montane (1800 to $2400 \mathrm{~m}$ asl) and the second order polynomial of the power function for upper montane ( 2400 to $2600 \mathrm{~m}$ asl) forests. In this study, we found that the three-parameter exponential function showed to be in general the best performing function for P. elata. However, at the site level, other allometric functions outperformed the three-parameter allometric function. When analyzed in function of habitat, we found that for sites located in semi-deciduous ("undisturbed") terra-firma forests (i.e. YBI1, BRO1 and MDR1), the Michaelis-Menten function had the best fit, concurring with Fayolle et al., (2016) and Loubota Panzou et al., (2018) for similar sites in Cameroon and Republic of Congo respectively. For sites located in natural disturbed terra-firma forests (i.e. YBI2, BRO2 and MDR2), the two-parameter exponential function showed better predictions. For sites located in plantation and in the seasonally flooded forest, the logistic function outperformed the others. Although different at the site-level, suitable allometric functions tend to converge at the habitat level. All sites in undisturbed semi-deciduous forest converge toward the Michaelis-Menten function while sites in disturbed natural forest converge toward the two-parameter exponential function. This result highlights the importance of human disturbances in the allometry of tropical trees as previously suggested by Sumida et al., (2013). Unfortunately, human disturbances are often ignored in H-D allometric equations of tropical trees (Kearsley et al., 2017). This is mainly due to the difficulty to record, date and quantify these disturbances. For the Congo Basin, the spatial distribution of deforestation and degradation suggested by Ernst et al., (2013) offers a possibility to include forest disturbances into the H-D allometric equations of Congo Basin trees.

\subsection{Site-specific allometric equations are preferable over global and even species level equations}

Site-specific variations in H-D allometric equation are widely reported in the tropical Africa using pooled-species datasets (Fayolle et al., 2016; Imani et al., 2017; Kearsley et al., 2017; Loubota Panzou et al., 2018a; Mensah et al., 2018). In this study, we found that the same pattern is observed for one particular species. Interestingly, we found that for the same diameter, trees are taller in DRC than in Cameroon. This result clarifies assumptions raised by Kearsley et al., (2013). They found that the average diameter of trees at the Dja reserve near Mindourou in Cameroon is significantly lower than at Yangambi in DRC. Consequently, they suggested that trees would grow taller in Cameroon than in DRC, in order to reach similar carbon stock. Our findings do not support this assumption, at least for P. elata. Despite a lower average tree diameter at Mindourou compared to Yangambi, trees reach higher height in the latter site. Since wood density does not vary between the two sites (Kearsley et al., 2013), we can conclude that, for the same diameter, trees of $P$. elata sustain higher biomass in DRC than in Cameroon. In this study, we were not able to include Mindourou in the analysis of the drivers of allometric variations between sites because stand variables were not available. Nevertheless, based on previous studies, we can list some possible drivers of allometric differences between DRC and Cameroon.

The first possible driver is climate. Despite insignificant differences in annual precipitation and average daily temperature between the Dja district in Cameroon and Yangambi in DRC (Kearsley et al., 2013), the climate is a little drier in the former site. The number of months receiving $<100 \mathrm{~mm}$ rainfall in Cameroon (4 months) is twice than in DRC ( 2 months). In addition, the climatic water deficit, as suggested by Chave et al., (2014), is highly negative at Mindourou (-207.13 mm.yr ${ }^{-1}$; Lon $=13.41$ and Lat $=3.58)$ compared to Yangambi $\left(-70.28 \mathrm{~mm} \mathrm{yr}^{-1}\right.$; Lon $=24.48$ and Lat $=0.80$ ). This suggests that at Mindourou trees experience a higher seasonal water stress than at Yangambi. This is in line with findings of Lines et al., (2012) showing that in water-stressed environments, tree height tend to be relatively smaller. Another possible explanation is related to the soil. In Yangambi forests, Kearsley et al., (2013) reported significantly lower $\mathrm{N}$ content compared to sites in the Dja reserve, suggesting a poor soil in the former site also because of their sandy nature. They therefore assume that the poorest nutrient status of Yangambi would be the cause of the lower canopy height found. However, in their study of the effects of soil chemistry on tropical forest biomass and productivity, Unger et al., (2012) found a significant negative relationship between top canopy height and nutrient content, especially $\mathrm{N}$ and $\mathrm{P}$ contents. They concluded that, at the stand level, top canopy height increases with a deterioration of the soil nutrient status. This finding is in line with our result highlighting higher heights for $P$. elata in Yangambi where a poor soil nutrient is found compared to Mindourou. We found similar patterns between sites in DRC. A study by Doetterl et al., (2015) comparing the soil of Yangambi with soil of the Yoko Reserve in DRC, revealed lower nutrient content, especially exchangeable $\mathrm{K}$ and $\mathrm{Na}$ contents, in Yangambi than in Yoko. This latter site is near Biaro $(\sim 3 \mathrm{~km})$ and Babusuko $(\sim 25 \mathrm{~km})$ and we assume that they would share similar soil properties, much more with Biaro. Interestingly, we found lower heights in Biaro and Babusoko than in Yangambi.

To determine the drivers of variation in H-D allometry of tropical trees, previous studies suggested stand-level competition as a potential driver. In most of these studies, stand-level competition is approximated through structural variables such as the basal area. At the pantropical level, it has been shown that forests with larger basal area tend to have taller trees for a given diameter (Feldpausch et al., 2011). This result is supported by our findings. We found that the maximum asymptotic height of P. elata increase with the stand-level basal area at the regional scale. Contrary to previous results, we do not find evidence of a climate effect on the H-D allometric relationship of $P$. elata. This would be due to the growing requirements of the species. As a light-demanding species, individual performances of $P$. elata is more associated with the local conditions (especially the competition for light). This assumption is supported by our findings. At the local-scale, we found the light availability at the tree crown level as a significant covariate in the H-D allometric equation of $P$. elata. Trees with higher light availability showed higher height for a given diameter and attained higher maximum asymptotic height. However, the positive effect of light availability on the H-D allometric relationship of $P$. elata is not to be associated with light only. As the Dawkins index (used as light availability variable) showed to be positively correlated with tree diameter, higher Dawkins value corresponds also to trees with higher diameter. Because tree diameter is also negatively correlated with tree-level competition, the effect of the Dawkins index is in fact in mixed effect of light and competition. We also showed that between-site differences in tree height are due to differences in crown depth rather than trunk height (Table 1). The inclusion of this crown depth in the local-scale H-D allometric equation of $P$. elata leads to a significant improvement of the model, suggesting that crown depth captured substantial part of variation in height growth trajectories. From a wood production perspective, this result suggests that trunk volume models would not be affected by the highlighted site-specific variation. 


\section{Conclusion}

The aim of this study was to develop an H-D allometric equation for the emergent species $P$. elata. We found that existing H-D models significantly underestimate the height, suggesting that they are inappropriate for $P$. elata and probably for other emergent species. We identified a strong site-specific variation in H-D allometry of $P$. elata and showed that stand-level basal area captured some portion of the site effects and outperformed climate variables. At the local-scale, we found that the light availability and the crown depth showed to be important drivers of the site-to-site variation in H-D allometric relationship. This result stresses the importance of management options in driving the productivity of the endangered tropical tree species $P$. elata. The refined H-D allometric equation developed in this study is recommended for management planning and estimation of growth and yield performance of $P$. elata and other emergent tree species.

\section{CRediT authorship contribution statement}

Chadrack Kafuti: Conceptualization, Methodology, Formal analysis, Investigation, Writing - original draft, Writing - review \& editing, Supervision. Jan Van den Bulcke: Conceptualization, Validation, Supervision. Hans Beeckman: Conceptualization, Methodology, Validation, Project administration, Supervision. Joris Van Acker: Supervision. Wannes Hubau: Supervision. Tom De Mil: Supervision. Hulda Hatakiwe: Investigation, Supervision. Brice Djiofack: Investigation, Supervision. Adeline Fayolle: Validation, Supervision. Grace Jopaul Loubota Panzou: Investigation, Supervision. Nils Bourland: Conceptualization, Methodology, Validation, Supervision.

\section{Declaration of Competing Interest}

The authors declare that they have no known competing financial interests or personal relationships that could have appeared to influence the work reported in this paper.

\section{Acknowledgements}

This study was performed under the framework of the project AFRORMOSIA implemented by the Royal Museum for Central Africa (RMCA) with the financial support of CITES BE (Belgian Committee of the Convention on International Trade of Endangered Species). The Center for International Forestry Research (CIFOR) and Resources \& Synergies Development (R\&SD) provided administrative and logistic supports. We are grateful to CFT ("Compagnie Forestière et de Transformation") for access to the permanent plot of Babusoko which is within their logging concession and for hosting the Nelder plantations. We thank Nestor Luambua, Donatien Musepena, Jean-Pierre Ngongo, Kibinda Bondele, Michel Mayani and Daris Mufaona for assistance during fieldworks. Chadrack Kafuti is funded by the Special Research Fund PhD Scholarship from Ghent University (BOF-01W01519). Field height and diameter measurements in Cameroon were funded by the asbl Nature + and facilitated by the DynAfFor project (http://www. dynaffor.org/) and the Pallisco timber company for logistic support.

\section{Funding source}

The Belgian committee of the Convention on International Trade of Endangered Species (CITES BE) funded this study. The funding source was not involved in the study design; in the collection, analysis and interpretation of data; in the writing of the manuscript; and in the decision to submit the article for publication.

\section{Appendix A. Supplementary material}

Supplementary data to this article can be found online at https://doi. org/10.1016/j.foreco.2021.119822.

\section{References}

Banin, L., Feldpausch, T.R., Phillips, O.L., Baker, T.R., Lloyd, J., Affum-Baffoe, K. Arets, E.J.M.M., Berry, N.J., Bradford, M., Brienen, R.J.W., Davies, S., Drescher, M., Higuchi, N., Hilbert, D.W., Hladik, A., Iida, Y., Salim, K.A., Kassim, A.R., King, D.A., Lopez-Gonzalez, G., Metcalfe, D., Nilus, R., Peh, K.S.H., Reitsma, J.M., Sonké, B., Taedoumg, H., Tan, S., White, L., Wöll, H., Lewis, S.L., 2012. What controls tropical forest architecture? Testing environmental, structural and floristic drivers. Glob. Ecol. Biogeogr. 21, 1179-1190. https://doi.org/10.1111/j.1466-8238.2012.00778. $\mathrm{x}$.

Bastin, J.F., Barbier, N., Réjou-Méchain, M., Fayolle, A., Gourlet-Fleury, S., Maniatis, D., De Haulleville, T., Baya, F., Beeckman, H., Beina, D., Couteron, P., Chuyong, G., Dauby, G., Doucet, J.L., Droissart, V., Dufrêne, M., Ewango, C., Gillet, J.F., Gonmadje, C.H., Hart, T., Kavali, T., Kenfack, D., Libalah, M., Malhi, Y., Makana, J. R., Pélissier, R., Ploton, P., Serckx, A., Sonké, B., Stevart, T., Thomas, D.W., De Cannière, C., Bogaert, J., 2015. Seeing Central African forests through their largest trees. Sci. Rep. 5, 1-8. https://doi.org/10.1038/srep13156.

Bastin, J.F., Rutishauser, E., Kellner, J.R., Saatchi, S., Pélissier, R., Hérault, B., Slik, F., Bogaert, J., De Cannière, C., Marshall, A.R., Poulsen, J., Alvarez-Loyayza, P., Andrade, A., Angbonga-Basia, A., Araujo-Murakami, A., Arroyo, L., Ayyappan, N., de Azevedo, C.P., Banki, O., Barbier, N., Barroso, J.G., Beeckman, H., Bitariho, R., Boeckx, P., Boehning-Gaese, K., Brandão, H., Brearley, F.Q., Breuer Ndoundou Hockemba, M., Brienen, R., Camargo, J.L.C., Campos-Arceiz, A., Cassart, B., Chave, J., Chazdon, R., Chuyong, G., Clark, D.B., Clark, C.J., Condit, R., Honorio Coronado, E.N., Davidar, P., de Haulleville, T., Descroix, L., Doucet, J.L., Dourdain, A., Droissart, V., Duncan, T., Silva Espejo, J., Espinosa, S., Farwig, N., Fayolle, A., Feldpausch, T.R., Ferraz, A., Fletcher, C., Gajapersad, K., Gillet, J.F., Amaral, I.L. do, Gonmadje, C., Grogan, J., Harris, D., Herzog, S.K., Homeier, J., Hubau, W., Hubbell, S.P., Hufkens, K., Hurtado, J., Kamdem, N.G., Kearsley, E., Kenfack, D., Kessler, M., Labrière, N., Laumonier, Y., Laurance, S., Laurance, W.F., Lewis, S.L., Libalah, M.B., Ligot, G., Lloyd, J., Lovejoy, T.E., Malhi, Y., Marimon, B.S., Marimon Junior, B.H., Martin, E.H., Matius, P., Meyer, V., Mendoza Bautista, C., Monteagudo-Mendoza, A., Mtui, A., Neill, D., Parada Gutierrez, G.A., Pardo, G., Parren, M., Parthasarathy, N., Phillips, O.L., Pitman, N.C.A., Ploton, P., Ponette, Q., Ramesh, B.R., Razafimahaimodison, J.C., Réjou-Méchain, M., Rolim, S.G., Romero-Saltos, H., Rossi, L.M.B., Spironello, W.R., Rovero, F., Saner, P., Sasaki, D., Schulze, M., Silveira, M., Singh, J., Sist, P., Sonke, B., Soto, J.D., de Souza, C.R., Stropp, J., Sullivan, M.J. P., Swanepoel, B., Steege, H. ter, Terborgh, J., Texier, N., Toma, T., Valencia, R., Valenzuela, L., Ferreira, L.V., Valverde, F.C., Van Andel, T.R., Vasque, R., Verbeeck, H., Vivek, P., Vleminckx, J., Vos, V.A., Wagner, F.H., Warsudi, P.P., Wortel, V., Zagt, R.J., Zebaze, D., 2018. Pan-tropical prediction of forest structure from the largest trees. Glob. Ecol. Biogeogr. 27, 1366-1383. https://doi.org/10.1111/geb.12803.

Bourland, N., Kouadio, L.Y., Lejeune, P., Sonké, B., Philippart, J., Daïnou, K., Fétéké, F., Doucet, J.-L., 2012. Ecology of Pericopsis elata (Fabaceae), an Endangered Timber Species in Southeastern Cameroon. Biotropica 44, 840-847. https://doi.org/ 10.1111/j.1744-7429.2012.00874.x.

Cano, I.M., Muller-Landau, H.C., Joseph Wright, S., Bohlman, S.A., Pacala, S.W., 2019. Tropical tree height and crown allometries for the Barro Colorado Nature Monument, Panama: A comparison of alternative hierarchical models incorporating interspecific variation in relation to life history traits. Biogeosciences 16, 847-862. https://doi.org/10.5194/bg-16-847-2019.

Chave, J., Réjou-Méchain, M., Búrquez, A., Chidumayo, E., Colgan, M.S., Delitti, W.B.C., Duque, A., Eid, T., Fearnside, P.M., Goodman, R.C., Henry, M., Martínez-Yrízar, A., Mugasha, W.A., Muller-Landau, H.C., Mencuccini, M., Nelson, B.W., Ngomanda, A., Nogueira, E.M., Ortiz-Malavassi, E., Pélissier, R., Ploton, P., Ryan, C.M., Saldarriaga, J.G., Vieilledent, G., 2014. Improved allometric models to estimate the aboveground biomass of tropical trees. Glob. Chang. Biol. 20, 3177-3190. https:// doi.org/10.1111/gcb.12629.

Dawkins, H.C., Field, D.R.B., 1978. A Long-term Surveillance System for British Woodland Vegetation C.F.I.

de Ridder, M., Toirambe, B., Van den Bulcke, J., Bourland, N., Van Acker, J., Beeckman, H., 2014. Dendrochronological potential in a semi-deciduous rainforest: The case of Pericopsis elata in central Africa. Forests 5, 3087-3106. https://doi.org/ 10.3390/f5123087.

Doetterl, S., Kearsley, E., Bauters, M., Hufkens, K., Lisingo, J., Baert, G., Verbeeck, H., Boeckx, P., 2015. Aboveground vs. belowground carbon stocks in African tropical lowland rainforest: Drivers and implications. PLoS One 10, 1-14. https://doi.org/ 10.1371/journal.pone.0143209.

Ernst, C., Mayaux, P., Verhegghen, A., Bodart, C., Musampa, C., Defourny, P., 2013. National forest cover change in Congo Basin: Deforestation, reforestation, degradation and regeneration for the years 1990, 2000 and 2005. Glob. Chang. Biol. 19, 1173-1187. https://doi.org/10.1111/gcb.12092.

Fayolle, A., Loubota Panzou, G.J., Drouet, T., Swaine, M.D., Bauwens, S., Vleminckx, J., Biwole, A., Lejeune, P., Doucet, J.L., 2016. Taller trees, denser stands and greater biomass in semi-deciduous than in evergreen lowland central African forests. For. Ecol. Manage. 374, 42-50. https://doi.org/10.1016/j.foreco.2016.04.033.

Feldpausch, T.R., Banin, L., Phillips, O.L., Baker, T.R., Lewis, S.L., Quesada, C.A., AffumBaffoe, K., Arets, E.J.M.M., Berry, N.J., Bird, M., Brondizio, E.S., De Camargo, P., Chave, J., Djagbletey, G., Domingues, T.F., Drescher, M., Fearnside, P.M., Franca, M. B., Fyllas, N.M., Lopez-Gonzalez, G., Hladik, A., Higuchi, N., Hunter, M.O., Iida, Y., Salim, K.A., Kassim, A.R., Keller, M., Kemp, J., King, D.A., Lovett, J.C., Marimon, B. S., Marimon-Junior, B.H., Lenza, E., Marshall, A.R., Metcalfe, D.J., Mitchard, E.T.A., Moran, E.F., Nelson, B.W., Nilus, R., Nogueira, E.M., Palace, M., Patiño, S., Peh, K.S. 
H., Raventos, M.T., Reitsma, J.M., Saiz, G., Schrodt, F., Sonké, B., Taedoumg, H.E., Tan, S., White, L., Wöll, H., Lloyd, J., 2011. Height-diameter allometry of tropical forest trees. Biogeosciences 8, 1081-1106. https://doi.org/10.5194/bg-8-10812011.

Feldpausch, T.R., Lloyd, J., Lewis, S.L., Brienen, R.J.W., Gloor, M., Monteagudo Mendoza, A., Lopez-Gonzalez, G., Banin, L., Abu Salim, K., Affum-Baffoe, K., Alexiades, M., Almeida, S., Amaral, I., Andrade, A., Aragão, L.E.O.C., Araujo Murakami, A., Arets, E.J.M., Arroyo, L., Aymard C., G.A., Baker, T.R., Bánki, O.S., Berry, N.J., Cardozo, N., Chave, J., Comiskey, J.A., Alvarez, E., De Oliveira, A., Di Fiore, A., Djagbletey, G., Domingues, T.F., Erwin, T.L., Fearnside, P.M., França, M.B., Freitas, M.A., Higuchi, N., Honorio C., E., Iida, Y., Jiménez, E., Kassim, A.R., Killeen, T.J., Laurance, W.F., Lovett, J.C., Malhi, Y., Marimon, B.S., Marimon-Junior, B.H., Lenza, E., Marshall, A.R., Mendoza, C., Metcalfe, D.J., Mitchard, E.T.A., Neill, D.A. Nelson, B.W., Nilus, R., Nogueira, E.M., Parada, A., S.-H. Peh, K., Pena Cruz, A., Peñuela, M.C., Pitman, N.C.A., Prieto, A., Quesada, C.A., Ramírez, F., RamírezAngulo, H., Reitsma, J.M., Rudas, A., Saiz, G., Salomão, R.P., Schwarz, M., Silva, N., Silva-Espejo, J.E., Silveira, M., Sonké, B., Stropp, J., Taedoumg, H.E., Tan, S., Ter Steege, H., Terborgh, J., Torello-Raventos, M., Van Der Heijden, G.M.F., Vásquez, R., Vilanova, E., Vos, V.A., White, L., Willcock, S., Woell, H., Phillips, O.L., 2012. Tree height integrated into pantropical forest biomass estimates. Biogeosciences 9 , 3381-3403. https://doi.org/10.5194/bg-9-3381-2012.

Hall, J.., Swaine, M.D., 1981. Distribution and ecology of vascular plants in a tropical rain forest, Geobotany. ed. Springer Science. https://doi.org/10.1007/978-94-0098650-3.

Hasenauer, H., Monserud, R.A., 1996. A crown ratio model for Austrian Forests. For. Ecol. Manage. 84, 49-60. https://doi.org/10.1016/0378-1127(96)03768-1.

Hubau, W., Lewis, S.L., Phillips, O.L., Al., 2020. Asynchronous carbon sink saturation in African and Amazonian tropical forests. Nature 579, 80-87. https://doi.org/ 10.1038/s41586-020-2035-0.

Imani, G., Boyemba, F., Lewis, S., Nabahungu, N.L., Calders, K., Zapfack, L., Riera, B., Balegamire, C., Cuni-Sanchez, A., 2017. Height-diameter allometry and above ground biomass in tropical montane forests: Insights from the Albertine Rift in Africa. PLoS One 12. https://doi.org/10.1371/journal.pone.0179653.

Kafuti, C., Bourland, N., De Mil, T., Meeus, S., Rousseau, M., Toirambe, B., Bolaluembe, P.-C., Ndjele, L., Beeckman, H., 2020. Foliar and Wood Traits Covary along a Vertical Gradient within the Crown of Long-Lived Light-Demanding Species of the Congo Basin Semi-Deciduous Forest. Forests 11, 35. https://doi.org/10.3390/ f11010035.

Kearsley, E., De Haulleville, T., Hufkens, K., Kidimbu, A., Toirambe, B., Baert, G., Huygens, D., Kebede, Y., Defourny, P., Bogaert, J., Beeckman, H., Steppe, K., Boeckx, P., Verbeeck, H., 2013. Conventional tree height-diameter relationships significantly overestimate aboveground carbon stocks in the Central Congo Basin. Nat. Commun. 4, 1-8. https://doi.org/10.1038/ncomms3269.

Kearsley, E., Moonen, P.C., Hufkens, K., Doetterl, S., Lisingo, J., Boyemba Bosela, F., Boeckx, P., Beeckman, H., Verbeeck, H., 2017. Model performance of tree heightdiameter relationships in the central Congo Basin. Ann. For. Sci. 74 https://doi.org/ 10.1007/s13595-016-0611-0.

Kearsley, E., Verbeeck, H., Hufkens, K., Doetterl, P.S., Baert, G., Beeckman, H., Boeckx, P., Huygens, D., 2016. Functional community structure of African monodominant Gilbertiodendron dewevrei forest influenced by local environmental filtering. Ecol. Evol. 00, 1-10. https://doi.org/10.1002/ece3.2589.

Kershaw, J.A., Morrissey, R.C., Jacobs, D.F., Seifert, J.R., McCarter, J.B., 2008. Dominant Height-Based Height-Diameter Equations for Trees in Southern Indiana. Proc. 16th Cent. Hardwoods For. Conf. 341-355.

King, D.A., 1996. Allometry and life history of tropical trees. J. Trop. Ecol. 12, 25-43. https://doi.org/10.1017/s0266467400009299.

Lam, T.Y., Kershaw, J.A., Hajar, Z.S.N., Rahman, K.A., Weiskittel, A.R., Potts, M.D., 2017. Evaluating and modelling genus and species variation in height-to-diameter relationships for Tropical Hill Forests in Peninsular Malaysia. Forestry 90, 268-278. https://doi.org/10.1093/forestry/cpw051.

Lewis, S.L., Lopez-gonzalez, G., Sonke, B., Affum-baffoe, K., Baker, T.R., Ojo, L.O., Phillips, O.L., Reitsma, J.M., White, L., Comiskey, J.A., Djuikouo, K., Ewango, C.E. N., Feldpausch, T.R., Hamilton, A.C., Gloor, M., Hart, T., Hladik, A., Lloyd, J., Makana, J., Malhi, Y., Mbago, F.M., Ndangalasi, H.J., Lovett, J.C., 2009. Increasing carbon storage in intact African tropical forests. Nature 457, 1003-1006. https:// doi.org/10.1038/nature07771.

Lines, E.R., Zavala, M.A., Purves, D.W., Coomes, D.A., 2012. Predictable changes in aboveground allometry of trees along gradients of temperature, aridity and competition. Glob. Ecol. Biogeogr. 21, 1017-1028. https://doi.org/10.1111/j.1466 8238.2011.00746.x.

Loubota Panzou, G.J., Fayolle, A., Feldpausch, T.R., Ligot, G., Doucet, J.L., Forni, E., Zombo, I., Mazengue, M., Loumeto, J.J., Gourlet-Fleury, S., 2018a. What controls local-scale aboveground biomass variation in central Africa? Testing structural, composition and architectural attributes. For. Ecol. Manage. 429, 570-578. https:// doi.org/10.1016/j.foreco.2018.07.056.

Loubota Panzou, G.J., Fayolle, A., Jucker, T., Phillips, O.L., Bohlman, S., Banin, L.F., Lewis, S.L., Affum-Baffoe, K., Alves, L.F., Antin, C., Arets, E., Arroyo, L., Baker, T.R.,
Barbier, N., Beeckman, H., Berger, U., Bocko, Y.E., Bongers, F., Bowers, S., Brade, T., Brondizio, E.S., Chantrain, A., Chave, J., Compaore, H., Coomes, D., Diallo, A., Dias, A.S., Dimobe, K., Djagbletey, G.D., Domingues, T., Doucet, J.L., Drouet, T., Forni, E., Godlee, J.L., Goodman, R.C., Gourlet-Fleury, S., Hien, F., Iida, Y., Ilondea, B.A., Ilunga Muledi, J., Jacques, P., Kuyah, S., López-Portillo, J., Loumeto, J.J., Marimon-Junior, B.H., Marimon, B.S., Mensah, S., Mitchard, E.T.A., Moncrieff, G.R., Narayanan, A., O'Brien, S.T., Ouedraogo, K., Palace, M.W., Pelissier, R., Ploton, P., Poorter, L., Ryan, C.M., Saiz, G., dos Santos, K., Schlund, M., Sellan, G., Sonke, B., Sterck, F., Thibaut, Q., Van Hoef, Y., Veenendaal, E., Vovides, A.G., Xu, Y., Yao, T.L., Feldpausch, T.R., 2021. Pantropical variability in tree crown allometry. Glob. Ecol. Biogeogr. 30 (2), 459-475. https://doi.org/ 10.1111/geb.13231.

Loubota Panzou, G.J., Ligot, G., Gourlet-Fleury, S., Doucet, J.L., Forni, E., Loumeto, J.J., Fayolle, A., 2018b. Architectural differences associated with functional traits among 45 coexisting tree species in Central Africa. Funct. Ecol. 32, 2583-2593. https://doi. org/10.1111/1365-2435.13198.

Mehtatalo, M.L., 2020. Package ' lmfor .' Available online from The Comprehensive R Archive Network.

Mensah, S., Pienaar, O.L., Kunneke, A., du Toit, B., Seydack, A., Uhl, E., Pretzsch, H., Seifert, T., 2018. Height - Diameter allometry in South Africa's indigenous high forests: Assessing generic models performance and function forms. For. Ecol. Manage. 410, 1-11. https://doi.org/10.1016/j.foreco.2017.12.030.

Meyer, H.A., 1940. A mathematical expression for height curves. J. For. 38, 415-420.

Molto, Q., Hérault, B., Boreux, J.J., Daullet, M., Rousteau, A., Rossi, V., 2014. Predicting tree heights for biomass estimates in tropical forests -A test from French Guiana. Biogeosciences 11, 3121-3130. https://doi.org/10.5194/bg-11-3121-2014.

Moravie, M.A., Durand, M., Houllier, F., 1999. Ecological meaning and predictive ability of social status, vigour and competition indices in a tropical rain forest (India). For. Ecol. Manage. https://doi.org/10.1016/S0378-1127(98)00480-0.

Moreno-Fernández, D., Álvarez-González, J.G., Rodríguez-Soalleiro, R., PasalodosTato, M., Cañellas, I., Montes, F., Díaz-Varela, E., Sánchez-González, M., CrecenteCampo, F., Álvarez-Álvarez, P., Barrio-Anta, M., Pérez-Cruzado, C., 2018. Nationalscale assessment of forest site productivity in Spain. For. Ecol. Manage. 417, 197-207. https://doi.org/10.1016/j.foreco.2018.03.016.

Pinheiro, J.C., Bates, D.M., 2000. Mixed-effects models in S and S-PLUS.

Pinheiro, J.C., Bates, D.M., DabRoy, S., Sarkar, D., 2019. nlme: linear and nonlinear mixed effects models.

Poorter, L., Bongers, L., Bongers, F., 2006. Architecture of 54 moist-forest tree species: Traits, trade-offs, and functional groups. Ecology 87, 1289-1301. https://doi.org/ 10.1890/0012-9658(2006)87[1289:AOMTST]2.0.CO;2.

Pretzsch, H., Biber, P., Uhl, E., Dahlhausen, J., Rötzer, T., Caldentey, J., Koike, T., van Con, T., Chavanne, A., Seifert, T., du Toit, B., Farnden, C., Pauleit, S., 2015. Crown size and growing space requirement of common tree species in urban centres, parks, and forests. Urban For. Urban Green. 14, 466-479. https://doi.org/10.1016/j. ufug.2015.04.006.

Preuhsler, T., 1981. Ertragskundliche Merkmale oberbayerischer BergmischwaldVerjüngungsbestände auf kalkalpinen Standorten im Forstamt Kreuth. Forstw. Cbl $100,313-345$.

Richards, F.J., 1959. A flexible growth function for empirical use. J. Exp. Bot. 10, 290-301. https://doi.org/10.1093/jxb/10.2.290.

Ritz, C., Baty, F., Streibig, J.C., Gerhard, D., 2015. Dose-response analysis using R. PLoS One 10, 1-13. https://doi.org/10.1371/journal.pone.0146021.

Rouvinen, S., Kuuluvainen, T., 1997. Structure and asymmetry of tree crowns in relation to local competition in a natural mature Scots pine forest $902,890-902$.

Sumida, A., Miyaura, T., Torii, H., 2013. Relationships of tree height and diameter at breast height revisited: Analyses of stem growth using 20-year data of an even-aged Chamaecyparis obtusa stand. Tree Physiol. 33, 106-118. https://doi.org/10.1093/ treephys/tps127.

Unger, M., Homeier, J., Leuschner, C., 2012. Effects of soil chemistry on tropical forest biomass and productivity at different elevations in the equatorial Andes. Oecologia 170, 263-274. https://doi.org/10.1007/s00442-012-2295-y.

Vanclay, J.K., 1994. Modelling forest growth and yield: applications to mixed tropical forests. CAB International, Wallingford, UK.

Verbeeck, H., Boeckx, P., Steppe, K., 2011. Tropical forests : include Congo basin Clarifying the use of ' prepubescent'. Nature 479, 179. https://doi.org/10.1038/ 479179b.

Vleminckx, J., Morin-Rivat, J., Biwolé, A.B., Daïnou, K., Gillet, J.F., Doucet, J.L., Drouet, T., Hardy, O.J., 2014. Soil charcoal to assess the impacts of past human disturbances on tropical forests. PLoS One 9. https://doi.org/10.1371/journal. pone. 0108121.

White, F., 1986. la végétation de l'Afrique, Orstom.

Worbes, M., 1995. How to Measure Growth Dynamics in Tropical Trees a Review. IAWA J. 16, 337-351. https://doi.org/10.1163/22941932-90001424.

Zhang, B., Sajjad, S., Chen, K., Zhou, L., Zhang, Y., Yong, K.K., Sun, Y., 2020. Predicting tree height-diameter relationship from relative competition levels using quantile regression models for Chinese fir (Cunninghamia lanceolata) in Fujian province, China. Forests 11, 1-15. https://doi.org/10.3390/f11020183. 